\title{
Pembuatan Alat Table Lathe untuk Menunjang Produksi Meubel Kayu UD. Mitra Abadi
}

\author{
Dewa Kusuma Wijaya ${ }^{1}$, Herwin Suprijono ${ }^{2}$, Kusmiyati $^{3}$ \\ ${ }_{1,2,3}$ Program Studi Teknik Industri, Universitas Dian Nuswantoro Semarang \\ E-mail: ${ }^{1}$ dewa.kuja@gmail.com, ${ }^{2}$ herwin.suprijono@gmail.com, ${ }^{3}$ kusmiyati2007@gmail.com
}

\begin{abstract}
Abstrak
UD. Mitra Abadi dalam proses produksi produk furniturenya memiliki kendala terkait pembuatan komponen furniture berdimensi silindris oleh karena keterbatasan alat. Sering kali pesanan konsumen tidak luput dari desain furniture yang menuntut beberapa bagian komponennya berdimensi silindris seperti kaki meja dan ornamen lain. Pembuatan komponen furniture berdimensi silindris tersebut membutuhkan mesin bubut (lathe) khusus kayu. Program pengabdian ini beriorentasi membuat alat bubut kayu dengan biaya ekonomis baik pembuatan dan operasional, dilengkapi dengan meja (table lathe) agar lebih ergonomis, dan mempertimbangkan aspek keamanan (safety) operasionalitas dari alat. Selain itu, dilakukan edukasi kepada UD. Mitra Abadi sebagai mitra terkait teknik operasi permesinan dan perawatan (maintenance) dari alat tersebut. Edukasi teknik operasi permesinan dan maintenance dari alat perlu dilakukan mengingat keterbatasan wawasan oleh mitra mengenai alat table lathe yang dibuat tersebut. Program pengabdian ini tidak hanya menghasilkan luaran berupa alat saja namun diharapkan mitra mampu mengoperasikan alat tersebut secara baik dan benar dan mampu melakukan maintenance ringan secara mandiri agar dapat menunjang produksi produk furniturenya dalam memenuhi permintaan dari konsumen.
\end{abstract}

Kata kunci: table lathe, ekonomis, ergonomis, safety, maintenance

\begin{abstract}
UD. Mitra Abadi in the production process of its furniture products is related to the manufacture of furniture components with cylindrical dimensions due to tools limitations. Often consumers do not order from furniture designs that require several cylindrical dimension components such as table legs and other ornaments. The making of cylindrical dimension furniture components requires special wood lathe. This program is oriented to make wood lathe with low costs of development and operational, also is equipped with a table (lathe table) to make it more ergonomic, and consider the safety aspect of tool operation. In addition, education to UD. Mitra Abadi related to machining operation and maintenance techniques of the tools. Education about the machining operation and maintenance techniques of the tools need to be done, it is because partner of this progam is limited in knowledge about this tools. This dedication program not only produces output consisting of tools, but it is expected that partner of this program able to operate this tools with correctly and able to do some minor maintenance independently in order to support the production of furniture products to meet customer demand.
\end{abstract}

Keywords: table lathe, economical, ergonomic, safety, maintenance 


\section{PENDAHULUAN}

Mesin bubut adalah suatu mesin yang dioperasionalkan dengan menggunakan prinsip kerja pemotongan. Prinsip kerja dari operasi kerja pembubutan pada dasarnya sama dengan operasi kerja mesin perkakas pemotong lain yaitu dengan membuat benda bulat dengan diameter tertentu dengan teknik penyayatan [1]. Cara kerja secara dari mesin bubut adalah dengan memutar benda kerja yang telah diletakkan ke pencekam (chuck) dengan motor penggerak kemudian dibentuk atau dipotong menggunakan mata pahat, benda kerja yang mampu diproses oleh mesin bubut diantaranya adalah logam dan kayu.

Program kegiatan pengabdian ini bermitra dengan UKM produksi meubel kayu rumahan UD. Mitra Abadi. Mitra tersebut memiliki beberapa permasalahan terkait dengan keterbatasan alat untuk memproses komponen meubel kayu yang memiliki dimensi silindris. Sebagai contoh beberapa komponen tersebut adalah kaki meja, kaki lemari, dan ornamen lain yang berdimensi silindris. Untuk membuat suatu komponen atau produk kayu dengan dimensi silindris tentu saja membutuhkan alat khusus yaitu mesin bubut kayu, sedangkan mitra tidak memiliki alat tersebut. Sejauh ini mitra hanya memanfaatkan alat-alat tangan dan listrik yang dimiliki untuk membuat komponen silindris tersebut, sehingga hasil yang diperoleh kurang berkualitas. Di lain sisi, permintaan dari konsumen terkait produk meubel sering kali memiliki desain yang tidak luput dari dimensi silindris pada tiap komponen dan ornamennya. Hal ini tentu saja membuat mitra kesulitan dalam memenuhi permintaan tersebut oleh karena keterbatasan alat.

Program pengabdian ini berorientasi untuk membantu mitra dalam hal pembuatan alat mesin bubut yang dilengkapi dengan meja (table lathe) beserta edukasi dari teknik operasi permesinan dan perawatan (maintenance) dari alat tersebut. Perancangan dan pembuatan dari alat table lathe ini mengacu dari beberapa penelitian yang telah dilakukan dan produk-produk mesin bubut kayu yang sudah ada di pasaran. Fokus dari pembuatan alat table lathe ini adalah ekonomis dalam biaya pembuatan dan operasional, ergonomis dalam operasional, dan tetap mempertimbangkan aspek keamanan (safety).

Mesin bubut kayu konvensional haruslah memiliki beberapa komponen utama diantaranya adalah kepala tetap dan poros, landasan, kepala lepas atau senter, dan dudukan penahan perkakas dan penahan perkakas. Senter sendiri memiliki beberapa jenis diantaranya adalah senter kerucut, senter mangkuk, senter garpu, dan senter sekrup. Masing-masing jenis senter tersebut memiliki peruntukan dan kelebihannya masing-masing. Untuk mata pahat di dalam penggunaan mesin bubut konvensional juga memiliki berbagai macam jenisnya, diantaranya adalah pahat kuku yang memiliki bentuk serong pada bagian tepi, pahat tusuk yang memiliki bentuk siku pada bagian tepi, pahat pemotong, dan lain sebagainya. Masing-masing pahat tersebut juga memiliki peruntukannya masing-masing di dalam memproses material kayu [2]. Perlu diketahui bahwa dalam penggunaan mesin bubut kayu konvensional mata pahat tidak dijepit seperti pada mesin bubut logam, namun pahat tersebut dipegang dan dioperasionalkan langsung oleh operator alat. Penggunaan dari pahat tersebut hanya dipegang dan diletakkan di penahan atau pendukung mata pahat, sehingga ketrampilan dari operator atau tukang kayu menjadi poin penting dalam keberhasilan proses membubut kayu.

Penelitian yang telah dilakukan terkait mesin bubut kayu menyatakan bahwa untuk putaran mesin 1400 RPM diketahui bahwa poros yang ideal berbahan FE490 dengan diameter $25 \mathrm{~mm}$, menggunakan bantalan P204, pulley berbahan ST70 diameter 5 dan $18 \mathrm{~cm}$, dan menggunakan sabun fan belt V-belt A dengan ukuran 44" [3]. Penelitian lain juga membandingkan tingkat kenaikan produktivitas produksi meubel furniture antara pemanfaatan mesin bubut kayu berbasis CNC dengan mesin bubut kayu konvensional dalam memproduksi produk. Diketahui bahwa mesin bubut kayu berbasis CNC mampu meningkatkan nilai produktivitas produk sebesar 35\%, sedangkan untuk mesin bubut kayu konvensional mampu meningkatkan nilai produktivitas produk mencapai 37\% [4]. Apabila kita analisis bahwasanya terdapat perbedaan sebesar $2 \%$ antara pemanfaatan mesin bubut berbasis CNC dengan mesin bubut kayu. Perbedaan tersebut memang tidak terlalu signifikan, namun apabila berbicara secara 
produksi masal (mass production) dan terkait dengan biaya operasional serta investasi maka tentu saja mesin bubut kayu konvensional. Mesin bubut kayu konvensional memiliki kelebihan yaitu selain rendah biaya investasi dan operasional, mesin tersebut juga diketahui cepat di dalam memproses material dibanding CNC serta mudah di dalam teknik operasi dan maintenance. Mesin bubut kayu konvensional tentu saja juga terdapat kekurangan yaitu membutuhkan ketrampilan dari operator untuk membubut kayu sesuai dengan desain yang diinginkan.

\section{METODE PELAKSANAAN}

\section{SURVEY PENDAHULUAN}

1. Observasi lapangan

2. Wawancara dengan mitra

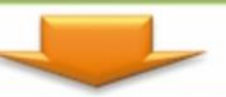

\section{RUMUSAN MASALAH}

1. Keterbatasan mesin bubut kayu untuk memproses material berdimensi silindris

2. Keterbatasan wawasan terkait operasionalitas dan maintenance mesin bubut kayu

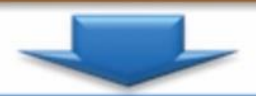

\section{SOLUSI}

1. Membuat mesin bubut meja (table lathe) dilengkapi fitur untuk meningkatkan nilai visibilitas dan safety yang baik

2. Edukasi teknik proses permesinan dan maintenance mesin table lathe

\section{TARGET}

1. Mitra mampu memanfaatkan secara intensif mesin table lathe dalam memproses produk dan komponen berdimensi silindris pada meubel kayu

2. Mitra mampu mengoperasikan dan melakukan maintenance mesin table lathe dengan baik dan tepat secara mandiri

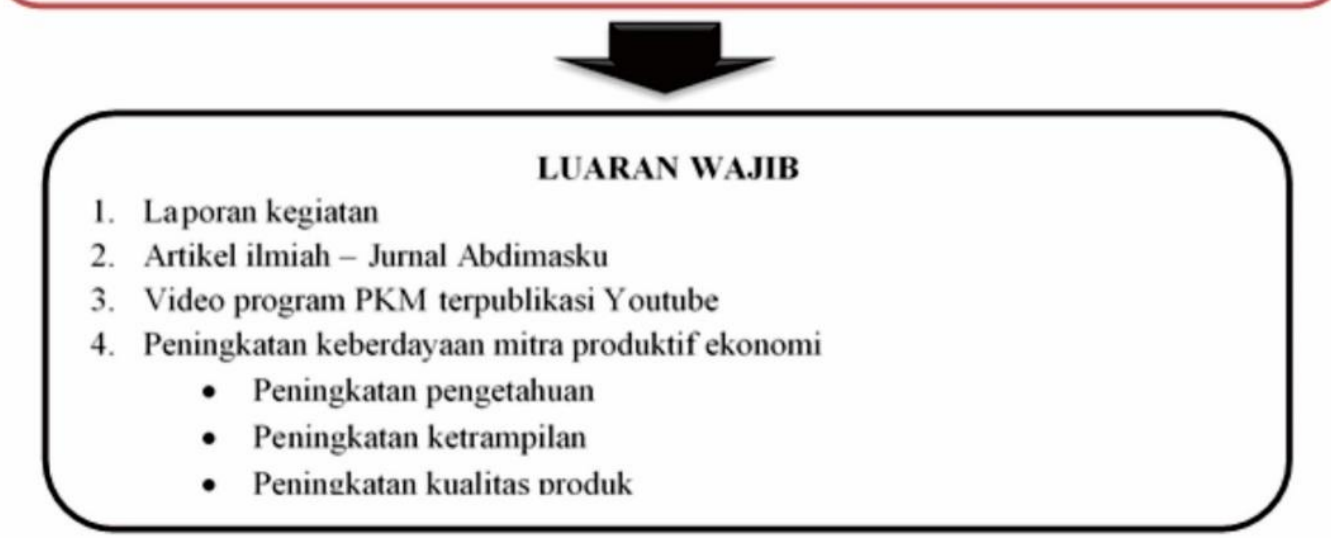

Gambar 1 Alur Program Pengabdian 
Berikut ini adalah struktur pelaksanaan dari program kegiatan pengabdian ini.

1. Survey pendahuluan

Dilakukan terlebih dahulu untuk mengidentifikasi kondisi aktual mitra meliputi observasi lapangan terhadap workshop mitra dan wawancara tidak terstruktur dengan mitra.

2. Rumusan masalah

Setelah kondisi aktual mitra teridentifikasi sebagai latar belakang permasalahan, selanjutnya merumuskan permasalahan berupa ketidaktersediaan alat bubut kayu untuk memproses komponen berdimensi silindris dan keterbatasan wawasan terkait teknik proses permesinan bubut

3. Solusi

Solusi merupakan bentuk strategi pemecahan masalah yang diterapkan kepada mitra program pengabdian. Adapun solusi program pengabdian ini adalah berupa pembuatan alat table lathe dan edukasi teknik proses permesinan dan maintenance dari alat tersebut.

4. Target

Target capaian dari program pengabdian ini adalah diharapkan mitra mampu memanfaatkan alat table lathe tersebut secara intensif di dalam menunjang produksi dan mitra mampu mengoperasikan alat tersebut secara baik dan benar serta melakukan maintenance ringan dari alat secara mandiri.

5. Luaran

Selain luaran wajib seperti yang ditunjukkan pada gambar 1 di atas, luaran tambahan program ini tidak hanya berupa alat tepat guna saja, namun juga pengetahuan dan ketrampilan tambahan bagi mitra serta peningkatan kualitas produk furniture di dalam memproduksi komponen berdimensi silindris.

Pada pembuatan alat table lathe dilakukan beberapa tahapan, diantaranya:

1. Penentuan mesin bubut kayu yang digunakan.

Mesin bubut yang diterapakan menjadi alat table lathe menggunakan merk Pazto.

2. Pengukuran secara anthropometri dari postur duduk pekerja pada mitra.

Bertujuan untuk mengetahui tinggi duduk pekerja yang ideal sehingga dapat menentukan tinggi dari meja alat bubut yang ergonomis.

3. Desain meja alat bubut.

Desain dari meja untuk alat bubut tersebut mengadopsi desain meja gergaji kuda atau yang dikenal sebagai saw horse dan menyesuaikan dengan luasan dasar mesin Pazto.

4. Penentuan material penyusun meja alat bubut.

Material untuk membuat meja bubut menggunakan bahan balok kayu mahoni oleh karena harganya yang relatif murah.

5. Pembuatan dan perakitan alat.

Pembuatan meja sesuai dengan desain saw horse yang telah dirancang sebelumnya menggunakan alat kerja berupa table saw, cordless drill, cordless impact driver, dan hand planner. Setelah setiap komponen meja dibentuk kemudian dilakukan perakitan (assembly) setiap potongan tersebut menjadi sebuah meja bubut dan diakhiri dengan pemasangan mesin Pazto di atas meja tersebut.

6. Pengujian alat.

Pengujian dari alat table lathe dilakukan setelah alat selesai dirakit tujuannya adalah 
untuk mengetahui tingkat ergonomi meliputi visibilitas dan kenyamanan penggunaan alat, performa dan kualitas hasil pengerjaan dari alat table lathe tersebut.

\section{HASIL DAN PEMBAHASAN}

Hasil dari program pengabdian yang telah dilakukan pada UD. Mitra Abadi berupa alat bubut tepat guna yang dilengkapi dengan meja atau table lathe. Table lathe yang dibuat tersebut mempertimbangkan aspek ekonomis dan ergonomis, adapun bentuk fisik dari alat table lathe tersebut seperti pada gambar 2 di bawah.

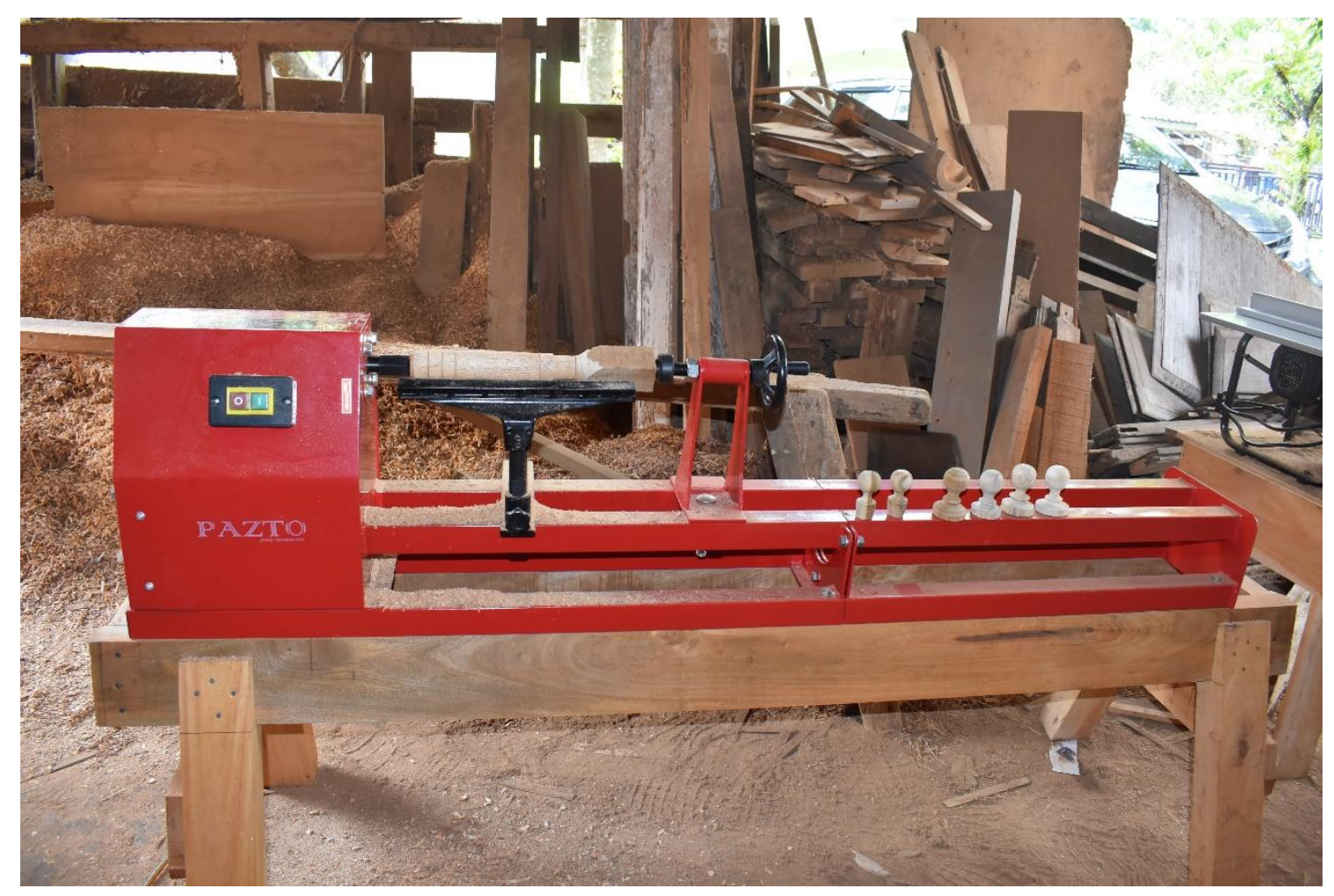

Gambar 2 Alat Table Lathe

Alat table lathe yang dibuat seperti pada gambar 2 di atas tersebut sebelumnya dirancang dengan mengambil data dari beberapa parameter pengukuran seperti anthropometri pekerja dan mesin yang digunakan. Spesifikasi teknis dari alat table lathe yang dibuat tersebut sendiri terbagi dari beberapa sub spesifikasi diantaranya meja bubut, mesin, kapasitas proses, dan fitur seperti yang ditunjukkan pada tabel 1 dibawah. 
Abdimasku, Vol. 3, No. 3, September 2020: 137-145

Tabel 1 Spesifikasi Teknis Alat Table Lathe

\begin{tabular}{lll}
\hline \multicolumn{1}{c}{ Parameter } & & Keterangan \\
\hline Meja bubut & $:$ Kayu mahoni \\
Bahan & $:$ Saw horse \\
Desain meja & $: \pm 50 \mathrm{~cm}$ \\
Tinggi dari dasar & $: \pm 140 \mathrm{~cm}$ \\
Panjang & $: \pm 40 \mathrm{~cm}$ \\
Jarak lebar antar kaki & $\pm 130 \mathrm{~cm}$ \\
Jarak panjang antar kaki & & \\
\hline Mesin bubut & $:$ & $\pm 30 \mathrm{~cm}$ \\
Panjang mesin & $:$ & $4000 \mathrm{watt}$ \\
Tinggi mesin & $:$ & $220 \mathrm{v}$ \\
Daya & $: 30 \mathrm{~kg}$ \\
Voltase & $: 4$ speed \\
Berat & $:$ \\
Kecepatan spindel & $: 100 \mathrm{~cm}$ \\
\hline Kapasitas proses & $: 35 \mathrm{~cm}$ \\
Max. cutting length & $\pm 75 \mathrm{~cm}$ \\
Max. cutting diameter & $:$ Ya \\
Tinggi chuck bubut dari dasar & $:$ Ya \\
\hline Fitur & \\
Saklar on-off & \\
Penahan/pendukung pahat &
\end{tabular}

Alat table lathe ini memiliki beberapa kelebihan diantaranya adalah dari sisi desain meja. Meja alat ini dirancang mengadopsi dari desain meja gergaji kuda atau yang dikenal sebagai saw horse, dinamakan demikian oleh karena desain meja tersebut menyerupai pelana kuda. Pemilihan desain meja saw horse ini berdasarkan dimensi dari mesin bubut kayu itu sendiri. Mesin bubut kayu yang digunakan memiliki dimensi panjang sekitar 1,3m dengan lebar sekitar $25 \mathrm{~cm}$, sehingga dapat dikategorikan mesin tersebut berdimensi ramping. Hal ini tentu saja menjadi keuntungan menggunakan meja saw horse oleh karena meja tersebut memiliki dimensi yang juga ramping namun sangat kokoh di bagian kaki-kaki yang pada aktualnya mampu menopang bobot mesin bubut kayu seberat $30 \mathrm{~kg}$ tersebut secara baik.

Dimensi dari meja saw horse tersebut dibuat dengan mempertimbangkan aspek ergonomis. Adapun ukuran dimensinya dapat dilihat pada tabel 1 di atas. Dalam merancang meja tersebut sebelumnya telah dilakukan pengukuran terhadap anthropometri dai pekerja pada mitra meliputi tinggi duduk, panjang kaki terhadap lutut, panjang lengan, dan lain sebagainya. Hasil dari pengukuran tersebut menghasilkan meja saw horse ergonomis seperti pada gambar 3 di bawah. Terlihat lutut dan kaki pekerja dapat berada di posisi di bawah meja yang membuatnya nayaman dalam bekerja, kemudian tingga lengan dengan senter mesin bubut pada posisi yang sama sehingga membuat pekerja dapat melakukan operasi pembubutan dengan mudah dan nyaman. Di lain sisi tinggi mesin bubut yang telah ditopang dengan meja saw horse tersebut membuat pekerja memperoleh visibilitas yang baik. 


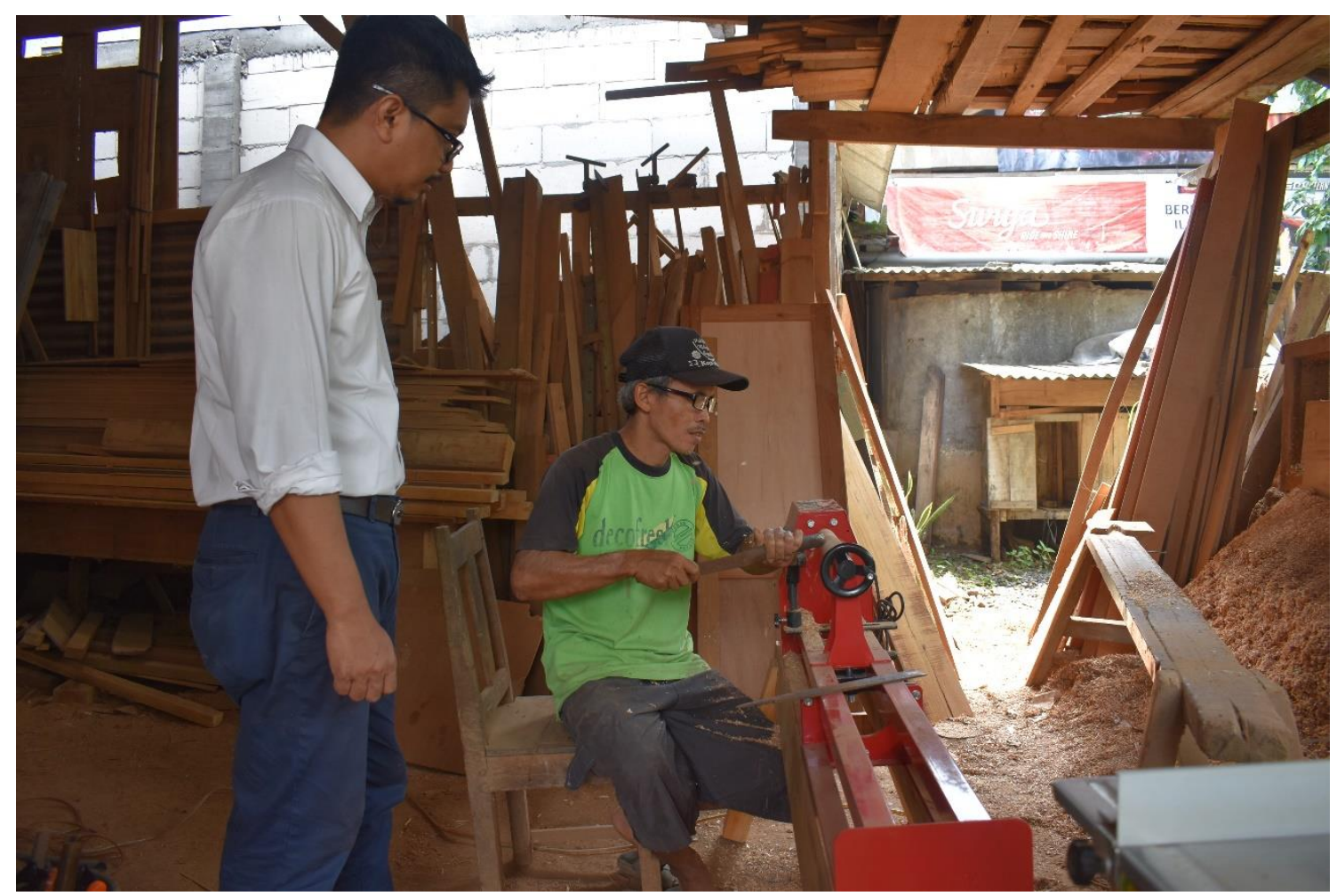

Gambar 3 Penggunaan Alat Table Lathe

Dari aspek biaya investasi meja saw horse yang dibuat menggunakan material kayu mahoni sambung, yang tentu saja biaya pembuatannya relatif terjangkau. Sedangkan dari aspek biaya operasional alat table lathe ini hanya menggunakan daya listrik sebesar 400 W dan biaya maintenance mesin hanya untuk pembelian minyak pelumas (grease) untuk melumasi motor dan bearing. Dari aspek safety alat ini juga telah dilengkapi saklar dan penahan untuk mata pahat, sehingga pekerja menjadi lebih aman di dalam melakukan operasi pembubutan kayu. Program kegiatan pengabdian yang dilakukan ini tidak sebatas membuat alat table lathe saja, namun juga mitra program diberikan edukasi terkait dengan teknik proses permesinan dan teknik untuk maintenance dari alat tersebut. Untuk teknik proses permesinan mitra diajarkan beberapa hal diantaranya operasionalitas dari alat, jenis senter mesin bubut kayu dan fungsinya, jenis pahat dan fungsinya, dan teknik proses pemahatan seperti pada gambar 4 di bawah. 


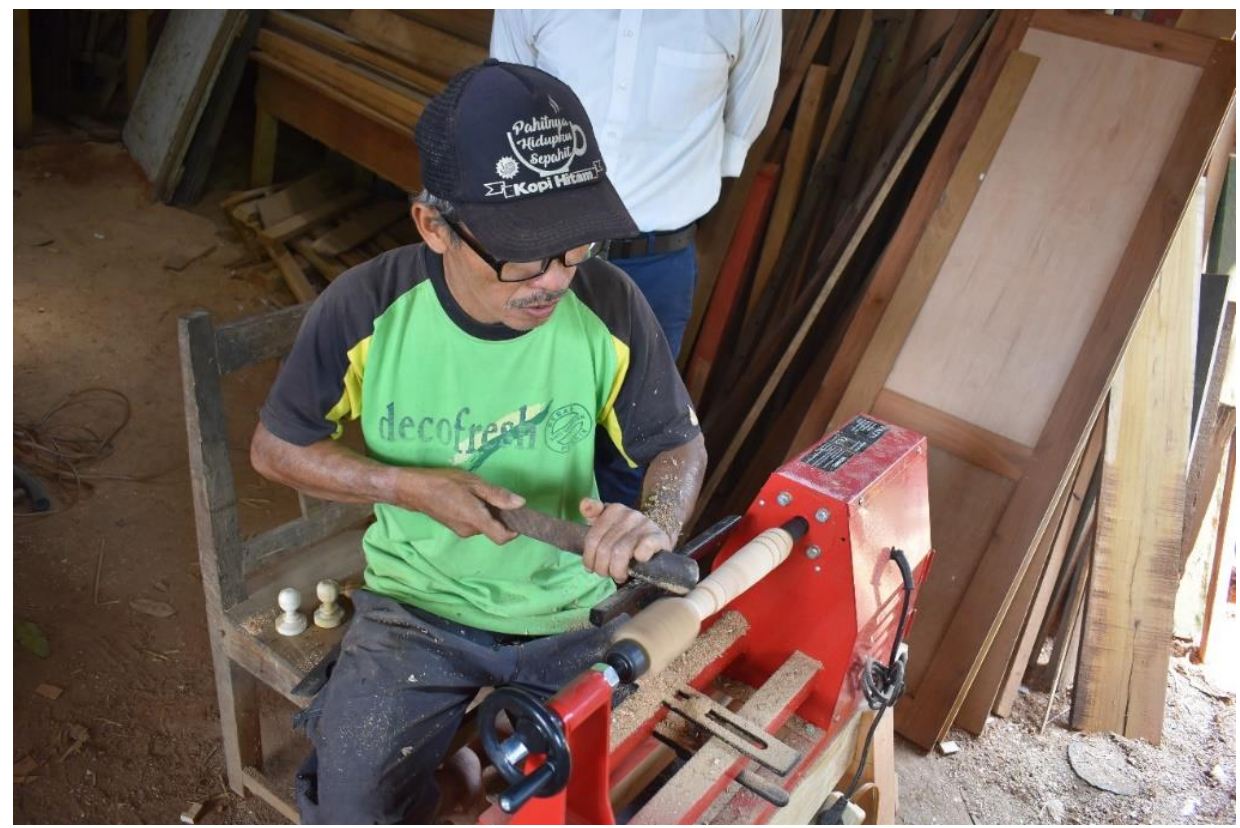

Gambar 4 Edukasi Teknik Proses Permesinan Alat Table Lathe

Teknik maintenance dari alat table lathe ini diantaranya adalah teknik inspeksi ringan dari alat meliputi inspeksi kelistrikan alat seperti kabel listrik, kondisi motor listrik pada mesin. Selanjutnya inspeksi mekanika alat meliputi putaran mesin, kondisi senter, penahan pahat, penjepit senter dan pahat, pelumas pada senter, chuck, bearing, dan motor listrik. Selain teknik inspeksi ringan mitra juga diedukasi terkait dengan teknik maintenance ringan dari alat table lathe tersebut, meliputi cara pemberian pelumas pada alat, cara perbaikan kabel listrik yang putus, cara memperbaiki kondisi chuck dan senter, dan cara mengencangkan setiap komponen pada alat seperti yang terlihat pada gambar 5 di bawah.

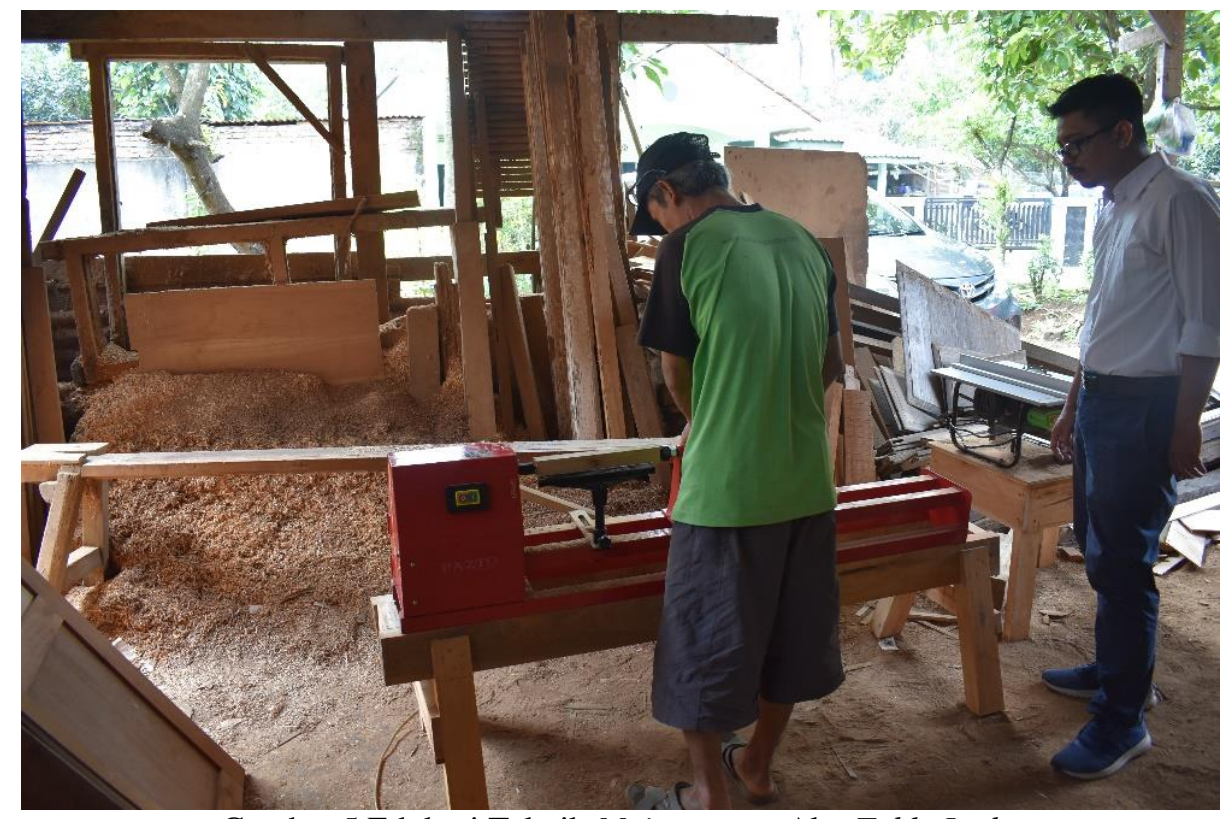

Gambar 5 Edukasi Teknik Maintenance Alat Table Lathe 


\section{KESIMPULAN DAN SARAN}

Kesimpulan dari program kegiatan pengabdian yang telah dilaksanakan pada UD. Mitra Abadi ini adalah sebagai berikut:

1. Alat table lathe yang dibuat sudah mempertimbangkan aspek ergonomis, hal ini dibuktikan dengan pemanfaatan meja bubut dengan mengadopsi desain saw horse yang sudah dirancang dengan mengukur anthropometri pekerja serta terbukti mampu meningkatkan kenyamanan bagi pekerja ketika mengoperasionalkan alat dan mampu meningkatkan visibilitas dari kerja pekerja tersebut.

2. Alat table lathe tersebut dibuat dengan biaya yang relatif ekonomis karena meja saw horse tersebut menggunakan potongan-potongan kayu mahoni yang disambung dan terkait biaya operasional dari alat tersebut juga relatif murah karena hanya menggunakan daya sebesar 400W serta kebutuhan grease untuk melumasi beberapa komponen utama alat sebagai bentuk maintenance ringan.

3. Alat table lathe tersebut sudah mempertimbangkan aspek safety bagi pekerja dalam operasionalitasnya, hal ini terbukti dengan adanya beberapa fitur seperti ketersediaan saklar mesin, kabel listrik yang terinsulasi dengan baik, dan didukung adanya penahan atau pendukung pahat yang memberikan rasa aman bagi pekerja ketika memahat.

Saran untuk program kegiatan pengabdian selanjutnya adalah mampu mengukur nilai efisiensi, efektifitas, dan produktivitas dari pemanfaatan alat table lathe tersebut. Selain itu dapat membantu mitra untuk pembuatan alat-alat produksi lain yang sangat dibutuhkan oleh mitra untuk menunjang produktivitas dan kualitas produk meubel, serta bentuk edukasi-edukasi lain terkait kondisi lingkungan produksi mitra seperti pengolahan limbah kayu, 5R, edukasi terkait tata letak dan fasilitas, dan lain sebagainya.

\section{UCAPAN TERIMA KASIH}

Pelaksana program kegiatan pengabdian ini mengucapkan banyak terima kasih kepada UD. Mitra Abadi selaku mitra program kegiatan dan LPPM Universitas Dian Nuswantoro Semarang yang telah mendanai program kegiatan pengabdian masyarakat secara internal sehingga pembuatan alat table lathe beserta edukasi kepada mitra mampu terealisasi dengan

baik. Link video kegiatan ini dapat diakses di

https://www.youtube.com/watch?v=88EpTQYeOk0

\section{DAFTAR PUSTAKA}

[1] Ardian Aan, 2010, Pengoperasian Mesin Bubut Kayu Kapasitas Diameter 700 mm, Program IbPE Fakultas Teknik Universitas Negeri Yogyakarta.

[2] Waludjojati.A. \& Purnomo, 2005, Analisa Gaya dan Kekuatan Rangka Mesin Bubut Kayu pada Industri Pembuatan "Sticky Billyard". Momentum, Vol.1, No.2, pp.33-38.

[3] Nawawi Imam R., 2016, Perencanaan dan Pembuatan Mesin Bubut Kayu dalam Mempercepat Proses Produksi, Skripsi Fakultas Teknik Universitas Muhammadiyah Ponorogo.

[4] Solechan dan Rubijanto, 2015, Meningkatkan Produktivitas Usaha Mebel Bubut Kayu (Wodd Lathe) di Desa Sekuro KEcamatan Mlonggo Kabupaten Jepara, Program IbM Kemenristekdikti Fakultas Teknik Universitas Muhammadiyah Semarang. 